\title{
Ethnozoological study of the wild pig (Sus spp.) hunting among Sundanese in Upper Citarum Watershed area, West Java, Indonesia
}

\author{
DEDE MULYANTO ${ }^{1, \vartheta}$, OEKAN S. ABDOELLAH ${ }^{2}$, JOHAN ISKANDAR ${ }^{3}$, BUDHI GUNAWAN ${ }^{2}$ \\ ${ }^{1}$ Graduate Program, Department of Anthropology, Faculty of Social and Political Sciences, Universitas Padjadjaran. Jl. Raya Bandung-Sumedang Km 21, \\ Jatinangor, Sumedang, 45363, West Java, Indonesia. Tel.: +62-22-7796416, `email: dedemulyantounpad@gmail.com \\ ${ }^{2}$ Department of Anthropology, Faculty of Social and Political Sciences, Universitas Padjadjaran. Jl. Raya Bandung-Sumedang Km 21, Jatinangor, \\ Sumedang, 45363, West Java, Indonesia \\ ${ }^{3}$ Department of Biology, Faculty of Mathematics and Natural Sciences, Universitas Padjadjaran. Jl. Raya Bandung-Sumedang Km 21, Jatinangor, \\ Sumedang, 45363, West Java, Indonesia
}

Manuscript received: 14 September 2021. Revision accepted: 21 October 2021.

\begin{abstract}
Mulyanto D, Abdoellah OS, Iskandar J, Gunawan B. 2021. Ethnozoological study of the wild pig (Sus spp.) hunting among Sundanese in Upper Citarum Watershed area, West Java, Indonesia. Biodiversitas 22: 4930-4939. In the past, wild pigs had a high population in the rural ecosystem of West Java. However, the population of wild pigs, particularly Javan warty pig, decreases due to forest destructions and intensive hunting. This study aimed to elucidate the local knowledge on wild pigs, the mode of hunting, and diverse aspects of wild pig hunting. We conducted qualitative methods with ethnozoological approach, including participant observation and in-depth interview. The results showed that based on the local people the wild pig can be divided into four "races", while based on zoology, two species of wild pig are documented in Java. During hunts all members get specific key roles. Thus, hunting success is increased by division of labor. Hunting wild pigs played an important role in socio-economic and cultural function for the village community. Due to intensive hunting of wild pigs, the population of these animals, particularly the Javan warty pig are decreased, and consequently the socio-economy of this animal in rural ecosystem may decrease ot even disappear.
\end{abstract}

Keywords: Hunting, pigdogging, Sus scrofa, Sus verrucosus, wild pig

\section{INTRODUCTION}

In Europe where hunters aim for sustainable hunting, hunting usually leads to an increase of species, especially in those species which should at least been regulated or even reduced (Keuling et al. 2013; Massei et al. 2015; Keuling et al. 2018; Tack 2018; Vaske et al. 2021; Gaskamp et al. 2021; Keuling and Massei 2021; Keuling et al. 2021). However, in other parts of the world, habitat loss and hunting animals are the two factors that cause the decline in wildlife (Harrison 2011, Mesquita and Barreto 2015, Constantino 2016; Tilker et al. 2019). Many factors drive the rampant hunting of wild animals. Apart from subsistence need (Rao et al. 2021; Santos-Fita et al. 2012; Pangan-Adam et al. 2012; Sanchez-Mercado et al. 2016; Quiros-Fernandez et al. 2017; Kusumaningrum et al. 2018), crop-raiding pest control (Parry et al. 2009; Campbell and Mackay 2003), and tourism (de Souza and Alves 2014; Buckley and Mossaz 2015; Muposhi et al. 2016; Ghasemi 2021; Minin et al. 2021), there is also a market for a game (Luskin et al. 2013; Lee et al. 2014; Sanchez-Mercado et al. 2016; Latinne et al. 2019; Yi and Mohd-Azlan 2020).

Changes in the conception of forest and wildlife from sacred to profane also significantly impact animal hunting (Permana et al. 2019; Masy'ud et al. 2020). In most parts of the tropics, this leads to an 'empty forest' situation in the sense that all bird and mammal species larger than approximately two kgs have either been extirpated or exist at densities well below natural levels of abundance (Harrison 2011; Benitez-Lopez et al. 2019).

In studies on resource use in Java, hunting wild animals have been neglected (Boomgaard 1997). The fact that hunting, as a significant claim to the use of natural resources in an agrarian society, has been underestimated might explain this neglection (Semedi 2010). However, hunting wild animals has never disappeared from rural Java over time. Wild pigs are some of the most hunted animals on this island (Suripto 2000).

One of the areas where wild pig hunting is still ongoing is the forested area of Priangan, West Java, which is mainly inhabited by the Sundanese (Semiadi and Meijaard 2004; Partasasmita et al. 2016). In the pre-Islamic period, the Sundanese have a strong relationship with pigs. Sundanese peasants raised igs as part of their productive activities, hunted wild pigs, sold their meat, and served pork as exceptional food (Nastiti 2006). Even until the early 18th century, when islamization was underway, they usually raised pigs near their dwellings (Stavorinus 1798I). Only in the 19th century, Chinese immigrants handled raising pigs (Raffles 1917 I). As in other Islamized areas, wild pigs have now been considered vermin (Boumendjel et al. 2017; Zainuddin 2019). However, conversion to Islam was an important turning point only for the consumption of pork, but not for the hunting of the wild boar (Boomgaard 1997). The continued hunting, some said, is because wild pigs are considered a pest (Partasasmita et al. 2016; Marsh et al 
2016). Their hunting is seen as part of the survival of agriculture (Boomgaard 1997).

Currently, there are two species of wild pigs on the island of Java, the wild boar Sus scrofa and Javan warty pig Sus verrucosus (Iskandar 2015; Rustiadi and Prihatini 2015; Frantz et al. 2016; Rode-Margono et al. 2017; Drygala et al. 2020). Globally, wild boars are not classified as an endangered species, and their population increased in the last decade (Risch et al. 2021). As endemic to Java, however, Javan warty pig is now classified as an endangered species and has seen dramatic population declines in recent years (Semiadi and Meijaard 2006). According to Indonesian law, both are not protected animals, so their hunting is not illegal. In agricultural area, hunting for wild pigs continues (Semiadi and Meijaard 2004). This situation was exacerbated by the fact that pig hunters would have to distinguish between different pig species but hunted indiscriminately. This may have impact on the success of future reintroduction efforts of Java warty pigs in West Java (Marsh et al. 2006).

Besides inquiries on local hunters' knowledge on wild pigs, in this study we also want to know the modes of hunting and its social, psychological as well as economic aspects so that we can find out why wild pigs are still being hunted.

\section{MATERIALS AND METHODS}

\section{Study area}

Our study was realized in the sub-district of Kertasari, district of Bandung, located in the extreme southeast of Upper Citarum Watershed area of West Java, Indonesia

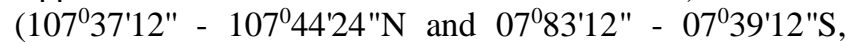

Figure 1), extending over an area of about $153 \mathrm{~km}^{2}$ at an average altitude of about $1700 \mathrm{~m}$ above sea level. The mountainous sub-district of Kertasari has a population of nearly 70,000 inhabitant. Kertasari has a wet tropical monsoon climate. The rainfall varies between 2000-3000 $\mathrm{mm}$ yearly. Rainfall can be torrential, especially from November to April. Generally, it is hot from July to midSeptember. The parent rock is sedimentary, especially volcanic, so fertility of the soil is suitable for agriculture.

In the past, the Kertasari had a large of natural forest. During the Dutch colonial period, part of the forest was opened and planted with quinine (Cinchona pahudiana Howard) and tea (Camellia sinensis L.). In post-colonial period, the management of these plantations was taken over by state-owned corporations. At this time, most of the forest area and quinine plantation have been converted into vegetable gardens. Various tree remains such as rasamala (Altingia excelsa Noronha) have been growing scattered among the vegetable gardens, with the lower part being grown by secondary forests (Figure 2).

Kertasari has a population density of 503 people per square kilometer. The main livelihood of the population is related to agriculture, with most farmers growing subtropical vegetables (Mulyanto et al. 2020). Irish potato (Solanum tuberosum L.) is dominant vegetable crop grown by farmers. In addition, other vegetables such as leek (Allium fistulosum L.), carrot (Daucus carota L.), and cabbage (Brassica oleracea L.), are cultivated. All vegetable crop products are sold. Only a few farmers cultivate over one hectare per year. As quantified in 2020, the average yields of vegetables were between 15-24 tonnes per hectare. However, most of the population are farm laborers. Some of them collect forest products and hunting wildlife to make ends meet (Hakim et al. 2020).

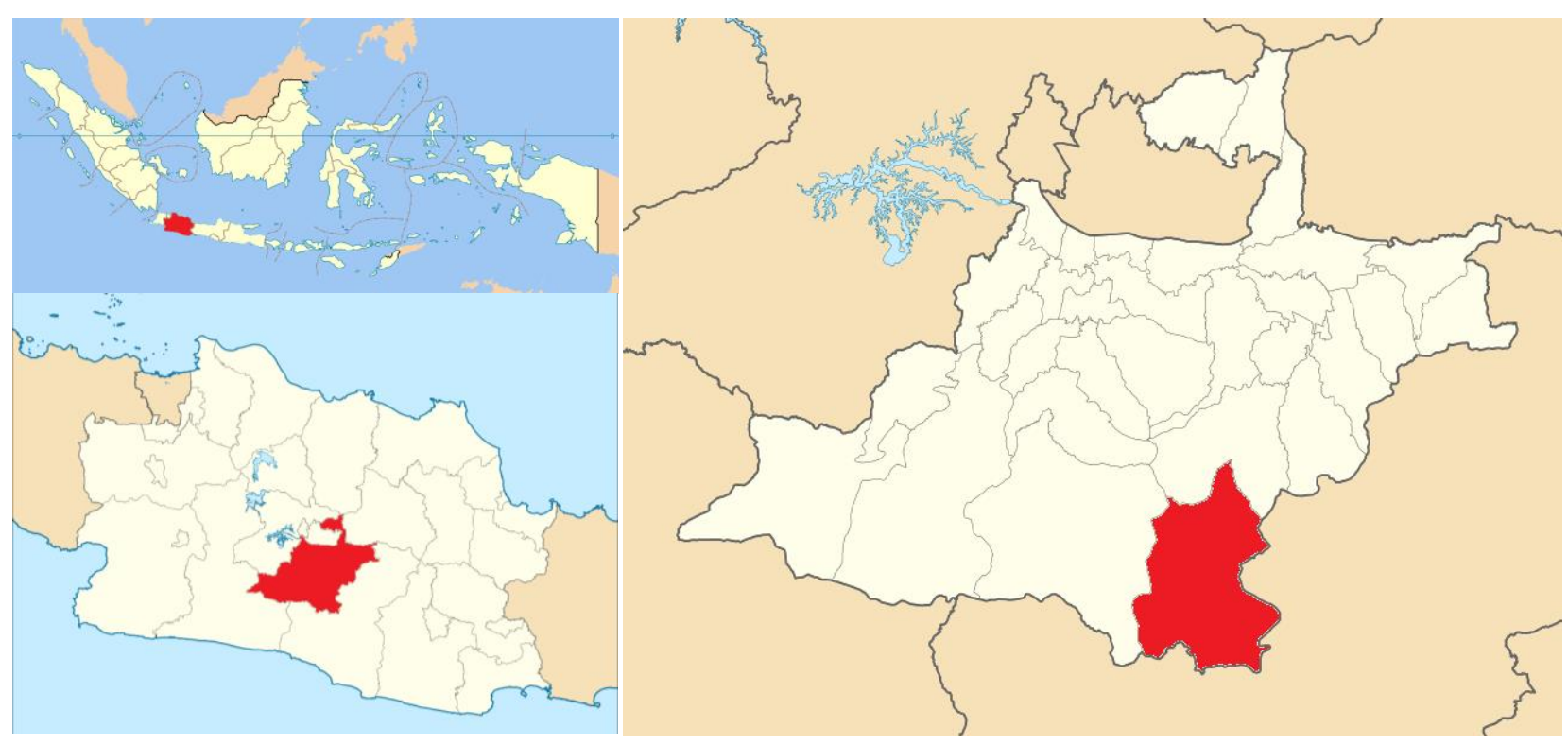

Figure 1. Location of Kertasari sub-district, Bandung, West Java, Indonesia 

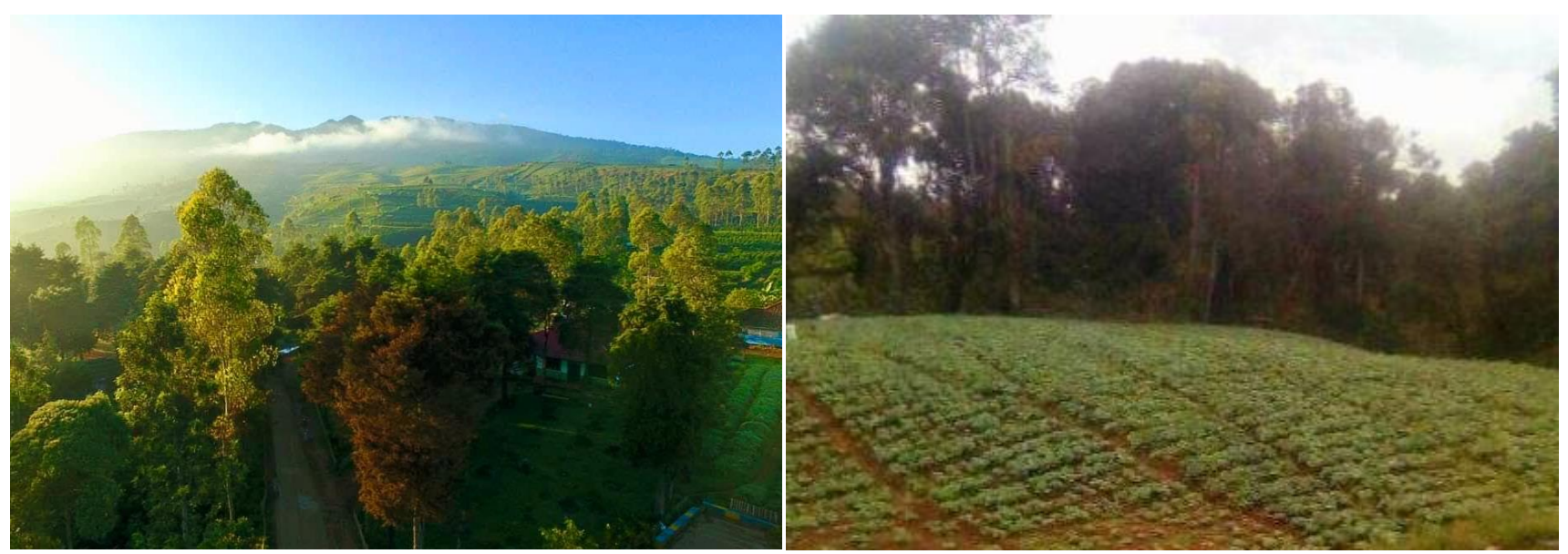

Figure 2. The forests have been predominantly converted to vegetable gardens

\section{Procedures}

The method used in this study was qualitative with an ethnozoological approach (Albuquerque et al. 2014; Vieira et al. 2014). The researchers conducted observations to record the general environmental conditions of the study area, including villages, agricultural lands, and the forest ecosystem. Participant observation was mainly conducted by companying some members of the wild boar hunting group to observe what they do and say, and to participate to varying degrees in the wild boar hunting activities studies. During the study, the researcher lived in the home of the local community, observed their daily activities, and conducted unstructured interviews, listening to gossip, and so on. The researcher lived in the local community three to five days per week for approximately one year, between August 2019 and November 2020. We conducted intensive research on hunting activity in November-December 2019 and September 2020.

A semi-structured in-depth interview was conducted with a competent informant by purposely selecting a snowball sampling technique. This technique was used for the intentional selection of informants. The working procedure was to find competent informants who profoundly knew ecological aspects of wild pig and wild pig hunting. The researcher worked with local experts on the set of socially legitimized individuals and recognized as holders of particular knowledge on wild pig hunting. From the initial contact with the community, the first expert is identified. This expert indicated another expert until the community experts are involved (Albuquerque et al. 2014).

Based on the snowball sampling technique, 26 wild pig hunters were collected. Each informant was asked specific question about hunting wild pigs, including their knowledge on wild pig behavior, hunting techniques and materials, hunting organization, and their motivations. Indepth interviews were conducted using the interview guide, which was general question discussed with informants, some of which arise naturally during the conservation (cf. Martin 1995). Interviews lasted approximately 20-30 minutes per informant and were conducted in Sundanese, the region's indigenous language.

\section{Data analysis}

The data obtained from observation and in-depth interviews were analyzed by cross-checking, summarizing, synthesizing, and building up a narrative account (Newing et al. 2011). Cross-checking was carried out to validate the data obtained from various informants, participant observation and secondary data. The data that has been validated were summarized and synthesized. Then a narrative was made in a descriptive and evaluative way.

\section{RESULTS AND DISCUSSION}

\section{Local knowledge on wild pigs}

One of the aspects of hunting is the hunter's knowledge of animals, behavior and ecology (Alves 2012; Keuling et al. 2016; Boumendjel et al. 2017; Keuling et al. 2021). The relationship between hunters and their prey, firstly, is through naming and classification. In the study area, the term babi is used only to refer to domesticated pigs. While, reference terms for wild pig are bagong, bedul, or céléng. All wild pig is called bagong biasa (ordinary wild pig). Based on local perception, there are four other specific names under bagong category: gagadungan, kanyéré, banén, and sinunggal.

The first name, gagadungan, refers to wild pigs whose main characteristic is warts or bumps on both sides of its face. The term gadung itself refers to intoxicating yam (Dioscorea hispida Dennst), a wild tuber commonly found in the secondary forests. In the past, its tuber was processed by removing the poison first as an alternative food. The face of $b$. gagadungan is considered to be similar to the shape of this bumpy yam. In addition, they also have a broader snout, enlarged body shape in the abdomen and base of the back limb, and usually pale brown, slightly reddish, or simply bright fur color. Zoologist identified this Sundanese name as (adult male of) Sus verrucosus (Semiadi and Meijaard 2004).

The second name, kanyéré is characterized by its black color, straight snout, with a slender build, only $40 \mathrm{~cm}$ tall, lives in the reeds, and known as the bravest to face humans. 
In local knowledge, the term kanyéré itself refers to the plant of Bridelia monoica Merr., small fruiting trees up to $6 \mathrm{~m}$ tall. This name probably refers to adult or old female Sus scrofa.

The third name, banén, refers to enormous will pig (more than $100 \mathrm{~kg}$ ), the average is between the range of 60$80 \mathrm{~kg}$. Fur color is gray and black. Prefers reeds but looks for food in gardens. About 20 years ago on group of banén could reach 30 heads, especially in the southern West Java forests. Probably this name refers to adult male of Sus scrofa. The name banén is also used in naming a plant, it refers to agidai (Crypteronia paniculata Blume) that is commonly found in tropical evergreen primary forest, 500$900 \mathrm{~m}$, with steeply ascending branches and can grow up to 30 meters tall. This plant is said to be a sign of the present of wild pigs in the vicinity.

The fourth name, sinunggal also refers to extraordinary large wild pigs similar to banén. Its name means 'a loner' who constantly roam alone on the forest floor. The hunters believe that this kind of wild pig is not an actual pig. He is a forest guardian (kuncen) who should be avoided immediately if encountering him on a hunt operation.

Based on habitat, hunters classify wild pigs into two general categories, namely bagong leuweung (literally mean forest pig) and bagong eurih (literally means a cogon grass-pig). The former live in the secondary forest and can be found in the open parts of the forest, while the second lives in the cogon-gass meadows.

Group hunters prefer to catch gagadungan and kanyéré. In addition to being more challenging because they were usually fiercer, the price was also higher if sold alive to the owner of the pig-dog fighting arena. From their own experiences, from the 1990s on gagadungan and kanyéré was more and more difficult to find. Only eight hunters had met them in the past five years. Mostly around the Sancang forest, South Garut district, about $50 \mathrm{kms}$ to the southeast from Kertasari and in rubber forest of Purwakarta and Subang district, nearly $80 \mathrm{~km}$ to the north from Kertasari.

Hunters also know about sexual dimorphism in wild pig, adult males (jalu) being larger than adult females (bikang). Males also usually roam alone, while females roam in group with other female and their piglets (begu). Their piglets also usually have light-colored stripes along their body, fading away as they get older.

In hunting, hunters heavily rely on dogs to locate and chase the pig. There are two types of dogs with different abilities to locate the pig: sniffer-by-air-dog (anjing pangingus) and sniffer-through-trail-dog (anjing pamacok tapak). Good hunting dogs being selected as young puppies (kirik) and named. Puppies with coriander-white-red-spoted color (katuncar mawur, refer to dried seeds or flower of Coriandrum sativum L.), deep dark eye retinas (kupa asak, refer to ripe fruits of Syzygium polycephalum (Miq.) Merr. \& Perry), and gripping sole (pancuh) or with claws like a cat's claw (ngaramo ucing, refer to Felis catus L.), coarse thick hair, black spot around the muzzle, and with towering-isosceles-triangle ear shape (ceuli rancung), is beliefs to have hereditary talent to be hunting dog.

When hunters get information about the presence of wild pigs in one place, either from farmer whose field is adjacent to the forest of from firewood collectors, the first step is to visit location and look for the presence of their footprints. If it is not there, the pangingus dog is deployed to track down. Whether it's following a trail or a scent, the tracking usually ends in a pig's nest (sudung), a wallow (panggupakan), feeding ground, a troop of pigs, or a lone male.

\section{Modes of hunting}

Based on ecological history, hunting wild animals, including wild pigs has been undertaken by local villagers in West Java since a long time (Iskandar 2018). However, there is no general inclusive term for 'hunting' in Sundanese tongues. The Indonesian verb 'berburu', 'to hunt', used when speaking with outsiders but almost never among residents, is usually translated as "moro", the most commonly used technique nowadays among locals. This is not to imply that moro is normally used to refer to all hunting methods, instead each hunting or animal-capture method is referred to by specific lexical item, all of which are taxonomically of the same level.

Wild pig hunting is commonly called as moro bagong or hunt-to-catch-alive method, which is the ambushing of fleeing wild pig by a group of hunters. This kind of hunt involves a division of labor between three key roles: the tracker (pangbitur) and his hounds who track and locate the wild pig, beaters (tukang nakol) and their hounds who dispel out the wild pig from the mountains and give chase it in the direction of the catchers (kiper, panewak) who wait along the likely escape routes of the wild pig (usually valley stream or mountain ridge).

Typically, there will be one or two pangbitur with two or three sniffer dogs; from two to six chasers, and one or two catchers strategically placed around the mountain. In principle, the larger the hunting group, the greater the chances of success. Tha tracker is the key player on whom all the other depend to track down the wild pig and drive it in their direction. Catchers are expected to consummate the work of chasers by catching when they gets the chance.

The number of hunting group members consists of six to fifteen people. All of them are men between the ages of twenty to fifty, with the majority $(65,3 \%)$ being under the age of forty years old (Tabel 1, Figures 3 and 4). They are mostly farm laborers and smallholder farmers with varying hunting experience (Tabel 1). In addition to using dogs, they also equip themselves with spears, ropes and a wooden drum (posong) or wooden box (porog) as a place to transport the hunted pig.

Other methods of wild pig hunting in study area can be diagnostically marked off. The first is ninggar or hunt-tokill method, a lair-stopping technique in which the wild pig is stopped at or near its lair (sudung) by the hound. This is solo hunting, involving a lone hunter and his hounds. The hounds are released to locate and counter the pig to prevent its run away, while the hunter, alerted by the hound's barking, runs to the scene to finish off the pig with his weapon. Among villagers, the lone hunter is called paninggaran. The most common weapon is the lance and a home-made firearms. This method is also used for hunting other small mammals. 


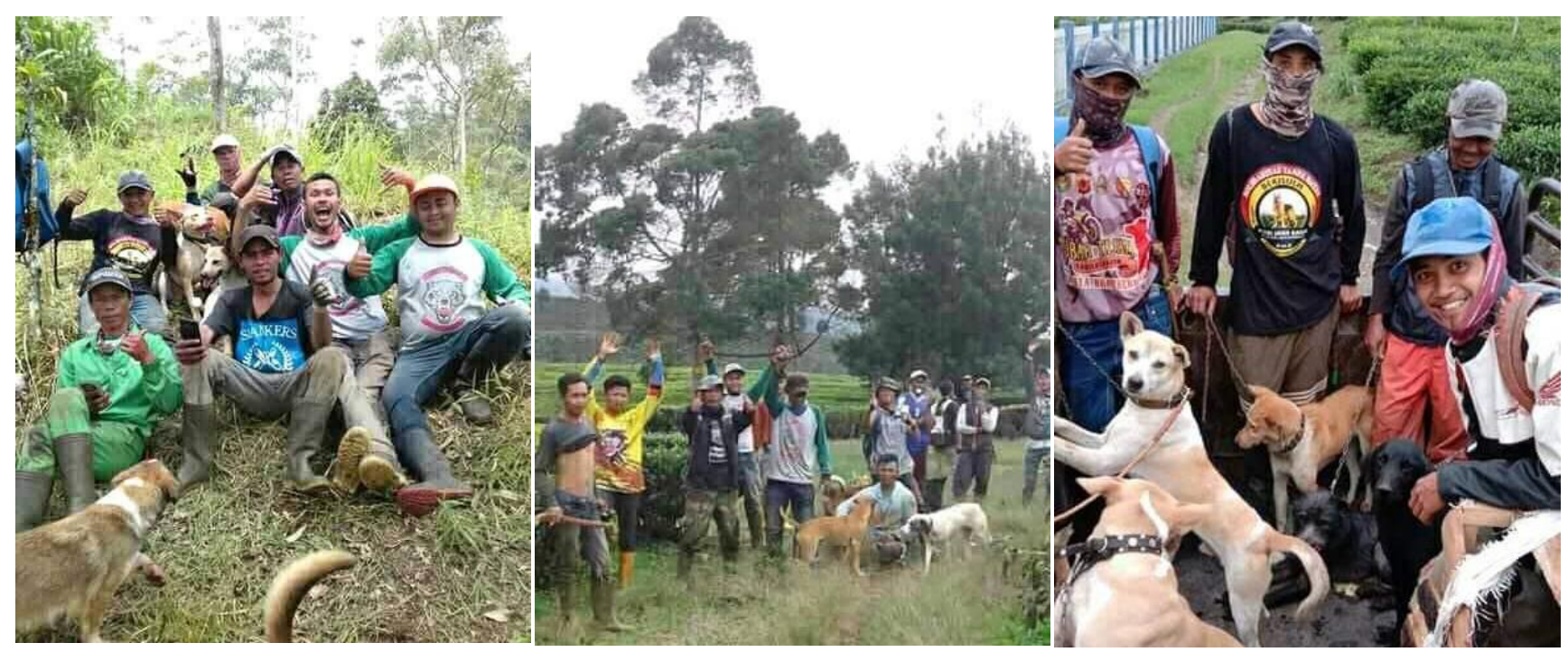

Figure 3. Three groups of wild pig hunter, accompanied by dogs consist of between 6-15 men individuals
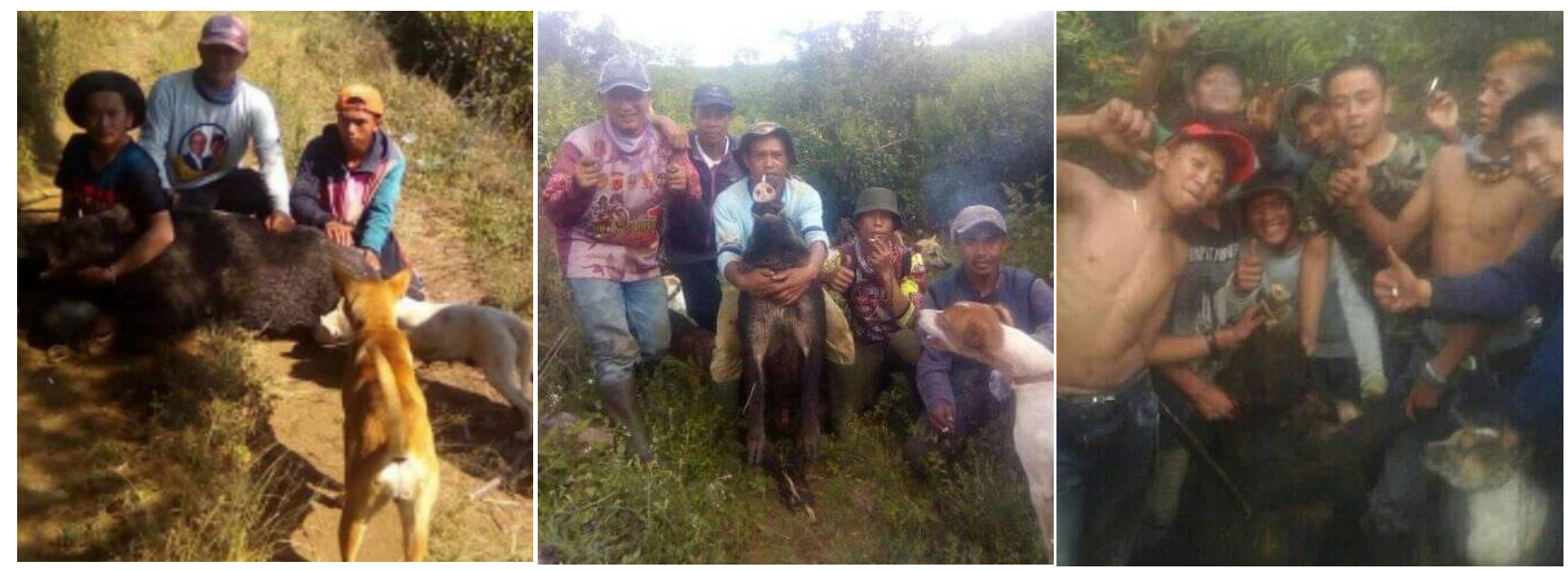

Figure 4. Three groups of wild pig hunter have just returned from moro bagong expedition and they got wild pig

The second and more popular solo hunting method is using nylon string snare (ngeurad). Snares are set on trails used regularly by the pigs, around wallows, salt-licks, and fruiting trees. In an operation that lasted about three to four days, a hunter can set 10-25 snares which are checked usually every evening. This mode of hunting is also used to catch other small mammals such as barking deer (mencek, Muntiacus muntjak), Asia palm civet (careuh bulan, Paradoxurus hermaphroditus), Small India civet (careuh dedes, Viverricula indica), and Javan mongoose (careuh ganggarangan, Herpestes javanicus).

Another method, using covered pit-fall (ngalobang), is now become rarely undertaken. Pit-fall, typically three meters squared by two meters deep, were dug on known pig trails and covered in vegetation, especially cogon grass (eurih), to disguise their presence. This entrapment were sometimes spiked to cause harm to the pig, sometimes not spiked to catch the pig alive.

\section{Social aspect}

Nowadays, person who other villagers call as paninggaran have become rare. During the study, only four persons from three families were documented as solo hunters in the study area (Tabel 1). They are low-income families whose livelihood is mainly from hunting wild animals, ranging from small mammals, and avifauna to insects. They usually hunt for anything as long as consumers demand these animals. Their social position is low in the village community.

On the other hand, although being a member of the group of hunters (tukang moro) is not what most young people dream of, their social status is higher than that of the paninggaran. For most tukang moro, the purpose of hunting is not to provide economic benefits. Instead, hunting is an intrinsically enjoyable activity that afford excitement, relaxation camaraderie, and a sense of collective and individual achievement when successful. Hunter variously characterizes is as an exercise (latihan), hobby or interest (hobi, resep), a play (uulinan), or sport 
(olahraga). Hunting is an all-consuming passion for some hunters, which occupies them even outside the hunting season through the year-round care of hounds through routine discussion and conversation about hound and hunting matters with fellow hunting dog owners. Hunting enables men to come together coordinated and pit themselves in a contest with other men.

The moro bagong hunt typically involves men who act as a team to flush out and catch the animal. These groups are of different sizes and have different degrees of organization and cohesion. With most groups, membership is fixed over time. Groups often consist of members of the same family and the relatives (for example, fathers and sons, brothers, uncles and nephews, cousins, and so on), peer group, and contain members from the same village or adjoining villages. Sometimes a group includes guests participating in the hunt such as a hunting-dog owner visiting "to train" his hound from the city of Bandung.

It is often said that hunting group todays have lost their cohesion because of the greater demands of family life. Some groups go out once a month in the wet season, but others convene only occasionally. Regularly in hunting is deemed because it allows a group to learn about game availability in the mountains and ensures that other groups do not have the chance to move in and take over a group's hunting ground.

There was no large-scale wild pig hunting involving almost all men in the village as in other parts of Java (Suripto 2000; Semedi 2010) or Sumatra (Zainuddin 2019). In study area, hunting is entirely the job of the hunters.

\section{Psychological aspect of hunting in group}

In the group hunting, hunters said that the wild pig hunt is a distinctive experience and refer to it as thrilling. They contend that those who have never deal with catching wild pigs cannot comprehend it. As one pig hunter put it, to catch one wild pig alive is better than capture a hundred birds. The fruitful wild pig hunt makes a taste of selfcomplacency (puas) in the hunter that other forms of hunting cannot cut out. The challenge of the wild pig hunt related to the specific attributes of the wild pigs. The fleeing wild pig infrequently allows itself to be sunk and getaways in the most harmful situations. One of the wild pig's action is to shift to the edge of its territory and then quietly turn back to circumnavigate its chasers (who may well be pitied keep on the pursuit into the secluded mountainous hinterland). Another pig deception, according to hunters, is to budge in a long zigzag path, to the great flurry and final frustration of hunters and hounds. Pig hunters also snitches themselves against the fighting spirit of the wild pig. The wild pig's emotional engagement with the hounds is one of the most thrilling moments of the hunt. Wild pig protrude from other forest animals because of the hazard it poses both to the hunter and his dogs. It is an offence animals with aggression that the bird entirely lacks.

Another aspects of the attraction of the pig-hunt is its "war-like" nature. As a time for men to exhibit boldness, power, and teamwork, pig-hunt is routinely connected to "warfare". There is an extensive lexicon of militaristic terminology employed by hunters. Pig-hunters refer to the hunt as a "battle" (perang), the hunting ground as a "battlefield" (palagan), a pause or stand-off in the hunt as an "armistice" (gencatan senjata), and so on. Pig-hunters even apply militaristic nomenclature to themselves; the lead hunter in one hunting group was known as the "captain" (kapten), while elsewhere high-handed hunters, always think they know the best are "mountain veteran" (veteran gunung). The war idiom readily extend to the wild pig itself.

The "war" with the wild pig has its human casualties. Through their encounters with catching wild pigs, hunters or their dogs endures solemn injuries (Figure 5). Many wild pig-hunter has scars to show from past "battle", usually on one of his limbs, especially the legs. The male wild pig, especially the biggest one usually roam by itself, known as sinunggal (the loner), is usually avoided. But female wild pigs are dangerous too because of their sheer physical power when charging and their ability to bite. Although direct attacks on hunters seldom occur, every pig-hunter knows that they are a possibility.
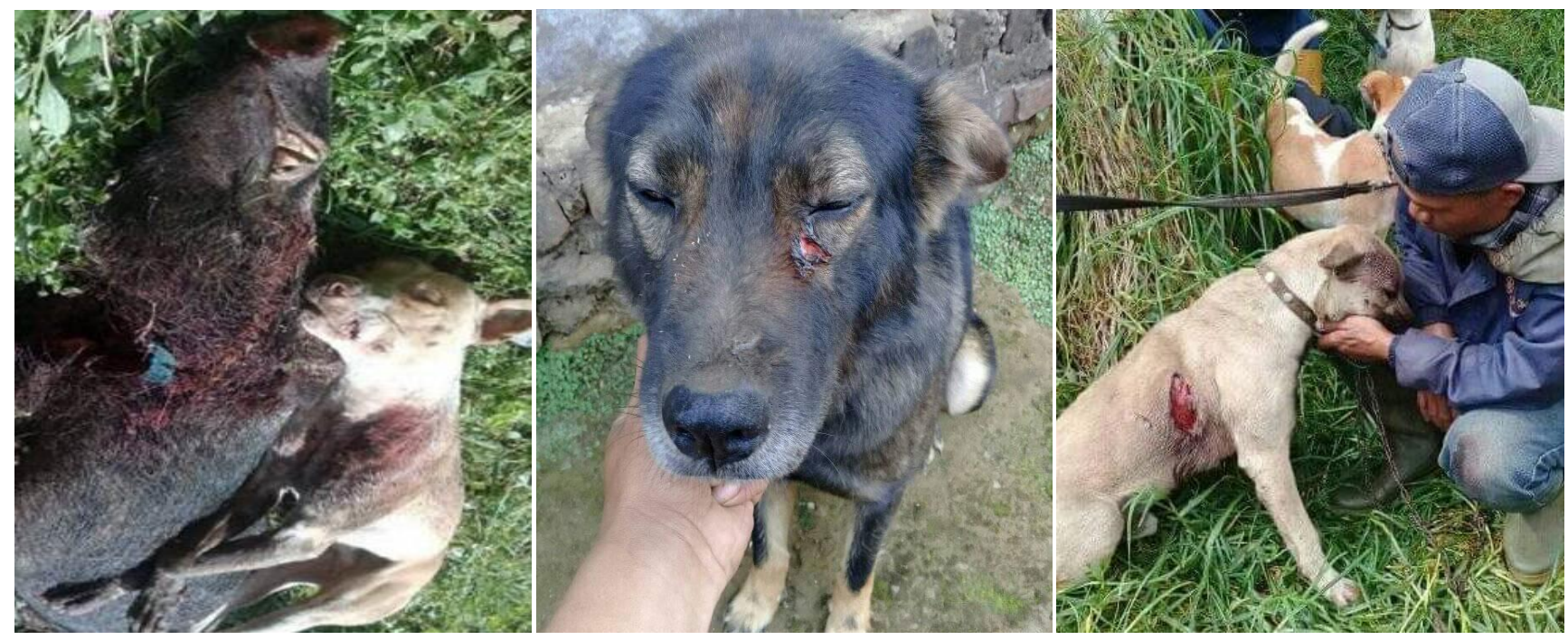

Figure 5. One dead and two dogs injured during hunting expedition 
Table 1. Personal characteristic, hunting behavior, and motivation of wild pig hunters in Kertasari, West Java, Indonesia

\begin{tabular}{|c|c|c|c|}
\hline Characteristic & Items & $\mathbf{n}$ & $(\%)$ \\
\hline Age (year) & $\begin{array}{l}20-29 \\
30-39 \\
40-49 \\
50-59 \\
\text { over } 59\end{array}$ & $\begin{array}{l}5 \\
12 \\
8 \\
1 \\
0\end{array}$ & $\begin{array}{l}19.2 \\
46.1 \\
30.7 \\
3.8 \\
0.0\end{array}$ \\
\hline $\begin{array}{l}\text { Hunting experience } \\
\text { (year) }\end{array}$ & $\begin{array}{l}0-4 \\
5-9 \\
10-14 \\
15-19 \\
\text { over } 19\end{array}$ & $\begin{array}{l}5 \\
6 \\
9 \\
4 \\
2\end{array}$ & $\begin{array}{l}19.2 \\
23.1 \\
34.6 \\
15.3 \\
7.7\end{array}$ \\
\hline Level of education & $\begin{array}{l}\text { Analphabet } \\
\text { Elementary school } \\
\text { Junior high school } \\
\text { Senior high scool } \\
\text { University }\end{array}$ & $\begin{array}{l}2 \\
10 \\
8 \\
6 \\
0\end{array}$ & $\begin{array}{l}7.7 \\
38.4 \\
30.7 \\
23.1 \\
0.0\end{array}$ \\
\hline Main occupation & $\begin{array}{l}\text { Farm laborer } \\
\text { Smallholder farmer } \\
\text { Self-employed }\end{array}$ & $\begin{array}{l}18 \\
5 \\
3\end{array}$ & $\begin{array}{l}69.2 \\
19.2 \\
11.5\end{array}$ \\
\hline $\begin{array}{l}\text { Average distance } \\
\text { traveled }(\mathrm{km})\end{array}$ & $\begin{array}{l}2-6 \\
7-11 \\
12-16 \\
\text { Over } 16\end{array}$ & $\begin{array}{l}12 \\
5 \\
6 \\
3\end{array}$ & $\begin{array}{l}46.1 \\
19.2 \\
23.1 \\
11.5\end{array}$ \\
\hline $\begin{array}{l}\text { Hunting frequency } \\
\text { per month }\end{array}$ & $\begin{array}{l}1 \\
2 \\
3 \\
4\end{array}$ & $\begin{array}{l}14 \\
6 \\
2 \\
4\end{array}$ & $\begin{array}{l}53.8 \\
23.1 \\
7.7 \\
15.3\end{array}$ \\
\hline $\begin{array}{l}\text { Main mode of } \\
\text { hunting }\end{array}$ & $\begin{array}{l}\text { Solo (ninggar) } \\
\text { In group (moro bagong) } \\
\text { Both }\end{array}$ & $\begin{array}{l}4 \\
20 \\
2\end{array}$ & $\begin{array}{l}15.3 \\
76.9 \\
7.7\end{array}$ \\
\hline $\begin{array}{l}\text { Hunting other } \\
\text { animals }\end{array}$ & $\begin{array}{l}\text { Yes } \\
\text { No }\end{array}$ & $\begin{array}{l}8 \\
18\end{array}$ & $\begin{array}{l}30.7 \\
69.2\end{array}$ \\
\hline Main motivation & $\begin{array}{l}\text { Subsistence } \\
\text { Leisure } \\
\text { Reducing damage }\end{array}$ & $\begin{array}{l}4 \\
12 \\
11\end{array}$ & $\begin{array}{l}15.3 \\
46.1 \\
42.3\end{array}$ \\
\hline
\end{tabular}

\section{Economic aspect}

For solo hunters, hunting wild pigs is a part of their livelihood activities. Even it is not provided meet for the family diet (because they are Muslim), the meat can always be sold to non-Muslim dealers in town. Solo hunter usually has their own meat dealers who regularly but they prey. They hunt singly or in pairs, especially with their adult son. They went to a hunting ground where they remain for three to six days to trap wild pigs before moving to a different forest area.

The meat usually sold by the piece to dealer. There is no difference in price between wild boar and Javan warty pig. Thus hunter obtain Rp. 25,000-75,000 for a kilogram from every game. Fluctuation in prices of the wild pig are hard to quantify. However, the following features have been observed. Usually, the price rises for celebrations for non-Muslim holidays such as Christmas (last week of
December) or Galungan (second week of April). Hunters are paid in cash by dealers at the forest edge or collection point. Rarely do hunters bring their prey home.

Christian Batak, Minahasan, and Balinese living in Bandung, 50 kilometers from the study area, have a strong preference for wild pig meat compared to a domestic pigs. There are many restaurants related to these ethnic groups in which wild pig-based dish is served in this city. Dealers and consumers cannot distinguish banded pig from Javan warty pig. However, only a tiny amount of the last was sold.

Legally, in Indonesia no rules are prohibiting the sale of wild boar meat. However, not all non-Muslim dealers resell it to their fellows. Some dealers also sell it to butchers who mix pork with beef (tukang oplos) and sell it in the traditional markets where most Muslims buy meat. Due to recently increased law enforcement against these illegal meat traders, hunters prefer to sell their prey to nonMuslim restaurant owners or dealers.

Even for tukang moro, the enjoyable hunting can bring economic rewards. Unlike solo hunters, their primary purpose is to train their dogs and catch wild pigs, dead or alive. The live game is commonly transported and sold to the owners of pig-dog fighting arenas (bandar adu bagong). That is why they do not equip themselves with lethal weapons such as firearms or sharp-edged spears because the more unharmed they prey is, the more expensive it will be. However, in hunting, a wild pig can be seriously injured or even die. If they are large enough (more than 50 kilograms), dead catches are usually butchered on the spot and sold to the meat dealer. If the size is small, it is usually used as material to train young dogs (peureuh).

The selling price of a game is determined by the size and type of wild pig. The bigger it is, the more expensive it is. The most expensive is gagadungan, adult males of Javan warty pigs with warty in their face which are known to be fiercest one. One pig, more than 150 kilograms, can be sold between one to four million Rupiahs.

\section{Wild pig as pest}

Despite the recreational character of the hunt, group hunters readily marked to it as serious activity. They gave the sound that while it may not strictly speaking be a job, it is a labor of sorts. Hunter sometimes characterize hunting as a form of public service. This idea of hunting as a kind of public service refers to the hunter's role as en eliminator of pests. The farmer will call on local hunters to catch or kill problem animals when wild pigs attacked their fields.

During the fieldwork, there were seven calls from farmers whose field was attacked by wild pigs group and eight from a firewood collector (tukang damel suluh) who claimed to have encountered a troop of wild pigs in the forests near their village. However, not all information about the presence of wild pigs was immediately responded to by assembling group members and go hunting. The decision to conduct hunting is also influenced by the agricultural cycle. The times of land preparation and harvesting are two times where there is usually no hunting activity. This is because the hunters are mostly farm 
laborers and smallholder farmers whose livelihoods depend on agricultural works. On these two occasions, there was an excellent demand for wage-laborer.

Solo hunter are actively hunting wild pigs. They are more opportunistic. Demand for wild pig meat increases. Thus, they usually do not hunt call on. At least they will be more active in December and April every year when the demand for wild pig meat increases.

Hunting may not nowadays be a significant livelihood activity in its own right, except for subsistence solo hunters. For others, hunting wild pigs is viewed as necessary support to the village livelihoods based on growing commercially valuable crops that are conceived vulnerable to wildlife depredation. In other words, the rationale of hunting in this upland region is protective rather than productive.

Based on state regulation, all hunting activities may only be carried out by citizens who already have a hunter ID card and hunting license from the forestry and environment service. However, no single hunters in the study area have both. To "legalize" their hunting activities, hunters usually become members of related "semi-official" organization such as PORBI (Persatuan Olahraga Buru Babi, Sport Hunting Pigs Association).

\section{Discussion}

The fact that hunters frame their pig hunts as partly public service, while enjoying the esoteric aspects of it as a thrill and a hobby, shows that this activity has a strong psychological and moral footing for its sustainability (cf. Reo and Whyte 2012, von Essen 2020). Moreover, there is also an economic incentive from this activity as there is always a market for dead or alive prey. As a 'serious leisure' (cf. von Essen 2019; von Essen and Tickle 2020), hunting wild pigs involves not only skill and perseverance, but also seen as serious in constituting societal labor.

The militeristic ethos infuses wild boar hunting in Western countries is also found in the study area where most hunters describe hunting as a battle. According to Mörner and Olausson (2017), this constitute and is constituted by the underlying notion of human as superior to nature. This hegemonic nature frame, it is suggested, suppress more constructive ways of framing the humannature relationship.

In many countries, intensive hunting for wild boar may be beneficial from conservation and economic perspectives. The cost of wild boar impact on other protected endangered animals and on agricultural land have been very high (Hamrick et al. 2011; Arnett and Southwick 2015; Summer et al. 2017; Quiros-Fernandez et al. 2017; Rosa et al. 2018; von Essen 2020; Williams et al. 2021). With the increasing population of wild boars and the decreasing number of hunters, the problem in these countries is how to manage the wild boars populations classified as an invasive species (Massei et al. 2011; Beasly et al. 2018).

In Java, the problem is different. The fact that there are two species of wild pigs with different statuses, the problem is how to prevent hunters from hunting the endangered Javan warty pig (Sus verrucosus). This species population has dropped dramatically in recent years (Semiadi and Meijaard 2006). Hunting wild pigs and abused of caught pigs for pig-dog fighting is still rampant in rural West Java. According to Marsh et al. (2016), this situation may have hampered the success of any future reintroduction attempts of Javan warty pig because pig hunter cannot identify different pig species and hunt them indiscriminately. However, contrary to this assumption, hunters in the study area know the differences between the two different wild pig species and prefer to catch Javan warty pigs alive because they are more expensive. Knowledge, rather than ignorance, can hinder efforts to reintroduce the endangered Javan warty pig. So, before the Javan warty pig is successfully included in the list of protected animals and before reintroduction events, socialization may be preventative enough to hinder pig hunters from capturing this species. The best way to reduce pressure on Javan warty pigs is to enforce fines for selling this species, especially for traditional pig-dog fighting blood sport, so the socialization must also target the organizers of this folk game. In this context, ethnozoological inquiries can be a worth asset to upgrade understanding of the roles played by animals from the perspective of local people (Alvez 2012; Alvez and Souto 2015; McPherson et al. 2016).

\section{ACKNOWLEDGEMENTS}

This paper's research and socialization would not have been possible without the financial support fo part of the Academic Leadership Grant (ALG) of Prof. Johan Iskandar, Ph.D., so we thank to Rector of Padjadjaran University who give financial support of this research. We would like to gratefully acknowledge all informants who generously shared knowledge with us. Special thanks to Umar Tarigan who assisted in conducting interviews with some informants in September 2020.

\section{REFERENCES}

Albuquerque UP, Paiva de Lucena RF, de Freitas Lins Neto EM. 2014. Selection of research participants. In: Albuquerque UP, Cruz da Cunha LVF, Paiva de Lucena RF, Alves RRN (eds.) Methods and Techniques in Ethnobiology and Ethnoecology. Humana Press, New York.

Alves RRN. 2012. Relationships between fauna and people and the role of ethnozoology in animal conservation. Ethnobiology and Conservation 1 (2): 1-69. DOI: 10.15451/ec2012-8-1.2-1-69.

Alves RRN, Souto WMS. 2015. Ethnozoology: a brief introduction. Ethnobiology and Conservation 4 (1): 1-13. DOI: 10.15451/ec2015-14.1-1-13.

Beasly JC, Ditchkoff SS, Mayer JJ, Smith MD, Vercauteren KC. 2018. Research priorities for managing invasive wild pigs in North America. The Journal of Wildlife Management. DOI: 10.1002/jwmg. 21436.

Benitez-Lopez A, Santini L, Schipper AM, Busana M, Huijbregt MAJ. 2019. Intact but empty forest? Patterns of hunting induced mammal defaunation in the tropics. PLoS Biol 17 (5): e3000247. DOI: 10.1371/journal.pbio.3000247.

Boomgaard P. 1997. Hunting and trapping in the Indonesian Archipelago, 1500-1950. In: Boomgaard P, Colombijn F, Henley D. (eds.) Paper Landscapes: Explorations in the Environmental History of Indonesia. KITLV Press, Leiden. 
Boumendjel FZ, Hajji GEM, Valqui J, Bouslama Z. 2017. The hunting trends of wild boar (Sus scrofa) hunters in northeastern Algeria Wildlife Biology in Practice 12 (2): 91-103. DOI: 102461/wbp.2016.12.9.

Buckley R, Mossaz A. 2015. Hunting tourism and animal conservation. Animal Conservation 18: 133-135.

Constantino PAL. 2016. Deforestation and hunting effects on wildlife across Amazonian indigenous lands. Ecology and Society 21 (2): 3. DOI: 10.5751.ES-08323-210203.

Drygala F, Semiadi G, Wirdateti, Rode-Margono J. 2020. Evidence of hybridisation between the common Indonesia banded pig (Sus scrofa vitattus) and the endangered Java warty pig (Sus verrucosus). Conservation Genetics 21 (3). DOI: 10.1007/s 10592-020-01304-3.

von Essen E, Tickle L. 2019. Leisure or labour: an identity crisis for modern hunting? Sociologia Ruralis 60: 1. DOI: 10.1111/soru.12271.

von Essen E. 2020. How wild boar hunting is becoming a battlegroud. Leissure Science 42 (5-6): 552-569.

Frantz L, Meijaard E, Gongora J, Haile J, Groenen MAM, Larson G. 2016. The evolution of suidae. Annual Review of Animal Bioscience. DOI: 10.1146/annurev-animal-021815-111155.

Gaskamp JA, Gee KL, Campbell TA, Silvy NJ, Webb SL. 2021 Effectiveness and efficiency of coral traps, drop nets and suspended traps for capturing wild pigs (Sus scrofa). Animals 11 (6): 1565

Ghasemi B. 2021. Trophy hunting as consevation: do the major ethical theories converge in opposition to trophy hunting? People and Nature 3: 77-87.

Hakim, L., O.S. Abdoellah, dan S. Withaningsih. 2020. 'Impact of agricultural crop type and hunting on bird communities of two villages in Bandung, West Java, Indonesia', Biodiversitas 21 (1): 57 66.

Hamrick B, Campbell T, Higginbotham B, Lapidge S. 2011. Managing invasion: effective measures to control wild pigs. The Wildlife Professional 41-42.

Harrison RD. 2011. Emptying the forest: Hunting and extirpation of wildlife from tepical nature reserves. BioScience 61 (11): 919-924.

Hartatik T, Soewandi BDP, Volkandari SD., Tabun AC, Sumadi, Widodo. 2016. Genetic identification of local pigs and imported pigs (landrace and duroc) based on cytochrome $\mathrm{b}$ sequence analysis. Biodiversitas 17 (1): 270-274.

Hewitt DG. 2015. Hunters and the conservation and management of white-tailed deer (Odocoileus virginianus). International Journal of Environmental Studies 72 (5): 839-849.

Iskandar J. 2015. Biodiversity of animal species: ecological functions for human being. Graha Ilmu, Yigyakarta [Indonesian].

Keil PG. 2021. Rank atmospheres: The more-than-human scentspace and aesthetic of a pigdogging hunt. Australian Journal of Anthropology 32 (S1): 96-113.

Keuling O, Baubet E, Duscher A, Ebert C, Fischer C, Monaco A, Podgorski T, Prevot C, Ronnenberg K, Sodeikat G, Stier N, Thurfjell H. 2013. Mortality rates of wild boar Sus scrofa L. in central Europe. European Journal of Wildlife Research 59 (6): 805-814. DOI: 10.1007/s 10344-013-0733-8.

Keuling O, Strau $\beta$ E, Siebert U. 2016. Regulating wild boar population is "somebody else's problem"! Human dimension in wild boar management. Science of Total Environment 554-555: 311-319. DOI 10.1016/j.scitotenv.2016.02.159.

Keuling O, Podgorski T, Monaco A, Melleti M, Merta D, Albrycht M, Genov PV, Gethoffer F, Vetter SG, Jori F, Scalera R, Gongora J. 2018. Eurasian wild boar Sus scrofa (Linnaeus, 1758). In: Melleti M Meijaard E (eds.) Ecology, Conservation and Management of Wild Pigs and Peccaries. Cambridge University Press, Cambridge.

Keuling O, Massei G. 2021. Does hunting affect the behavior of wild pigs? Human-Wildlife Interaction 15 (1): 11. DOI: $10.26077 / 3 \mathrm{a} 83$ 9155.

Keuling O, Strau $\beta$ E, Siebert U. 2021. How do hunters hunt wild boar? Survey on wild boar hunting methods in the Federal State of Lower Saxony. Animals 11 (9): 2658. DOI: 10.3390/ani11092658.

Kusumaningrum EN, Supriatna J, Abinawanto, Bowolaksono A. 2018 Short communication: Ethnzoology-The perception of Tobelo Dalam tribal community in Saolat village, East Halmahera, Indonesia towards cuscus (Phalangeridae). Biodiversitas 19 (6): 2140-2146.

Latinne A, Saputro S, Kalengkongan J, Kowel CL, Gaghiwu L, Ransaleleh TA, Nangoy MJ, Wahyuni I, Kusumaningrum T, Safari D, Feferholtz Y, Li H, Hagan E, Miller M, Francisco L, Daszak P, Olival KJ, Pamungkas J. 2019. Characterizing and quantifying the wildlife trade network in Sulawesi, Indonesia. Global Ecology and Conservation 21. DOI: 10.1015/j.gecco.2019.e00887.

Lee TM, Sigouin A, Pineda-Vasquez M, Nasi R. 2014. The harvest of wildlife for bushmeat and traditional medicine in East, South, and Southeast Asia: current knowledge base, challenges, opportunities and areas for future research. Occasional Paper 115. CIFOR, Bogor.

Luskin MS, Christina ED, Kelley LC, Potts MD. 2013. Modern hunting practices and wild meat trade in the oil palm plantation-dominated landscapes of Sumatra, Indonesia. Human Ecology. DOI: 10.1007/s 10745-013-9606-8.

Marsh C, Wirdateti, Nekaris KAI. 2016. 'Crop raiding by Sus scrofa leads to pig fighting arenas in West Java'. Suiform Soundings 14 (2): 2023

Massei G, Roy S, Bunting R. 2011. Too many hogs? A review of methods to mitigate mpact by wild boar and feral hogs. Human-Wildlife Interactions 5 (1): 79-99.

Martin GJ. 1995. Ethnobotany: A Methods manual. Chapman \& Hall, London.

Massei G, Kindberg J, Licoppe A, Gacic D, Sprem N, Kamler J, Baubet E, Hohmann U, Monaco A, Ozolins J, Cellina S, Podgorski T, Fonseca C, Markov N, Pokorny B, Rosell C, Nahlik A. 2015. Wild boar populations up, numbers of hunters down? A review of trends and implications for Europe. Pest Management Science 71 (4): 492-500. DOI: $10.1002 /$ ps.3965.

Masy'ud B, Felayati NR, Sunarminto T. 2020. Local wisdom in animal conservation and animal use as medicine of Orang Rimba in Bukit Duabelas National Park, Jambi. Jurnal Manajemen Hutan Tropika 26 (1): 72-79.

McPherson JM, Sammy J, Sheppard DJ, Mason JJ, Brichieri-Colombi TA, Moehrenschlager A. 2016. Integrating traditional knowledge when it appears to conflict with conservation: lessons from the discovery and protection of sitatunga in Ghana. Ecology and Society 21 (1): 24. DOI: $10.5751 / \mathrm{ES}-08089-210124$.

Mesquita GP, Barreto LN. 2015. Evaluation of mammals hunting in indigenous and rural localities in Eastern Brazilian Amazon. Ethnobiology and Conservation 4 (2): 1-14.

Minin ED, Clements HS, Correla RA, Cortes-Capano G, Fink C, Haukka A, Hausmann A, Kulkami R, Bradshaw CJA. 2021. Consequences of recreational hunting for biodiversity conservation and livelihoods. One Earth 4. DOI: 10.1016/j.oneear.2021.01.014.

Mörner C, Olausson U. 2017. Hunting the beast on YouTube: The framing of in social media. Nordicom Review 38 (1): 17-29. DOI: 10.1515/nor-2016-0038.

Mulyanto D, Iskandar J, Madani A, Gunawan R, Partasasmita R. 2020. Folk name and lore birds from Sundanese of West Java, Indonesia: An-ethnoornithological survey. Biodiversitas 21 (9): 4384-4395. DOI:

Muposhi VK, Gandiwa E, Bartels P, Makuza SM. 2016. Trophy hunting, conservation, and rural development in Zimbabwe: issues, options, and implications. International Journal of Biodiversity. DOI: 10.1155/2016/8763980.

Nastiti, T.S. 2006. 'Old Sundanese community', In: T. Simanjuntak, M. Hisyam, B. Prasetyo, T.S. Nastiti (eds.) Archaeology: Indonesian Perspective, h. 424-447. LIPI, Jakarta.

Newing H, Eagle CM, Puri RK, Watson CW. 2011. Conducting research in conservation: social science methods and practice. Routledge, London and New York.

Olderman J. 2020. Hunting as conservation in the United Statessustaining suitble habitat. //corescholar.libraries.wright.edu/econ_student_paper_economies/3.

Pangan-Adam M, Noske R, Muetilenberg M. 2012. Wildmeat or bushmeat? Subsistence hunting and commercial harvesting in Papua (West New Guinea), Indonesia. Human Ecology 40: 611-621.

Partasasmita R, Iskandar J, Malone N. 2016. Karangwangi people's (South Cianjur, West Java, Indonesia) local knowledge of species, forest utilization and wildlife conservation. Biodiversitas 17 (1): 154161.

Permana S, Iskandar J, Parikesit, Husodo T, Megantara EN, Partasasmita R. 2019. Changes of ecological wisdom of Sundanese people on conservation of wild animals: A case study in Upper Cisokan Watershed, West Java, Indonesia. Biodiversitas 20 (5): 1284-1293.

Quiros-Fernandez F, Marcos J, Acevedo P, Gortazar C. 2017. Hunters serving the ecosystem: the contribution of recreational hunting to wild boar population control. European Journal of Wildlife Research. DOI: 10.1007/s10344-017-1107-4.

Raffles TS. 1817. The History of Java. 2 volumes. London: Black, Parbury, and Allen dan John Murray. 
Rao M, Zaw T, Htun S, Myint T. 2011. Hunting for a living: wildlife trade, rural livelihoods and declining wildlife in the Hkakaborazi National Park, North Myanmar. Environmental Management 48: 158167.

Reo NJ, Whyte KP. 2012. Hunting and morality as elements of traditional ecological knowledge. Human Ecology 40: 15-27. DOI: 10.1007/s 10745-011-9448-1.

Risch DR, Ringma J, Price MR. 2021. The global impact of wild pigs (Sus scrofa) on terrestrial biodiversity. Scientific Reports 11: 13256, DOI: 10.1038/s41598-021-92691-1.

Rode-Margono EJ, Rademaker MA, Semiadi G, Bulk S. 2017. 'Javan warty pig Sus verrucosus (Boei, 1832) and Bawean warty pig Sus blouchi (Groves and Grubb, 2011)', in M. Melletti \& E. Meijaard (eds.) Ecology, Conservation and Management of Wild Pig and Peccaries, pp. 193-201. Camrbridge: Cambridge University Press

Rosa CAD, Wallau MO, Pedrosa F. 2018. Hunting as the main technique used to control wild pigs in Brazil. Wildlife Society Bulletin 42 (1): 111-118.

Rustiadi R, Prihatini W. 2015. Javan leopard (Panthera pardus melas Cuvier,1809) and its potential prey in Bodogol, Gunung. National Park Gunung Pangrango. Pro. Sem. Nas. Masy Biodiv Indon 1 (2): 236-241 [Indonesian].

Sanchez-Mercado A, Asmussen M, Rodriguez-Clark K, Rodriguez JP, Jedrzejewski W. 2016. Using spatial patterns in illegal wildlife uses to reveal connection between subsistence hunting and trade. Conservation Biology 30 (6): 1222-1232.

Sanders HN, Hewitt DG, Perotto-Baldivieso HL, Vercauteren KC, Snow NP. 2020. Invasive wild pigs as primary nest predators for wild turkey. Scientific Reports 10: 2625. DOI: 10.1038/s41598-59543-w.

Santos-Fita D, Naranjo EJ, Rangel-Salazar JL. 2012. Wildlife uses and hunting patterns in rural communities of the Yucatan Peninsula, Mexico. Journal of Ethnobiology and Ethnomedicine 8: 38. DOI: 10.1186/1746-4269-8-38.

Semedi P. 2010. Wild Pig hunting in Petungkriono. Humaniora 22: 1-13.

Semiadi G, Meijaard E. 2004. Survey of the Javan Warty Pig ( $\mathrm{S} u$ s verrucosus) on Java and Bawean Island. Coopertion between Pusat Penelitian Biologi-LIPI and IUCN/SSC Pigs, Peccaries and Hippos Specialist Group, Bogor.
Semiadi G., Meijaard E. 2006. Declining populations of the Javan warty pig Sus verrucosus. Oryx 40 (1): 50-56.

Souza JB de, Alves RRN. 2014. Hunting and wildlife use in Atlantic forest remnant of Northeastern Brazil. Tropical Conservation Science. DOI: $10.1177 / 194008291$.

Summers J, Bradley MJ, Johnson A, Sharp KL. 2017. Viability of hunting as a means of wild hog population management of federal property. Kentucky Journal of Undergraduate Scholarship 1 (1): 52-62.

Suripto BA. 2000. Wild Boar (Sus spp.) in Java: past, present, and future. Jurnal Konservasi Kehutanan 2 (1): 1-23 [Indonesian].

Tack J. 2018. Wild Boar (Sus scrofa) Populations in Europe: a scientific review of population trends and implications for management. European Landowners' Organization, Brussels.

Tilker A, Abrams JF, Mohamed A, Nguyen A, Wang ST, Sollmann R, Niedball J, Bhagwat T, Gray TNE, Rawson BM, Guegen F, Kissing J, Wegmann M, Wilting A. 2019. Habitat degradation and indiscriminate hunting differentially impact faunal communitis in the Southeast Asian tropical biodiversity hotspot. Communications Biology 2: 396. DOI: 10.1038/s42003-019-0640-y.

Vaske JJ, Miller CA, McLean HE, Jaebker LM. 2021. Beliefs, perceived risks and acceptability of lethal management of wild pigs. Wildlife Research 48 (3): 202-208. DOI: 10.1071/WR19207.

Vieira KS, Vieira WLS, and Alves RRN. 2014. An introduction to zoological taxonomy and collection and preparation of zoological specimens. In Albuquerque UP, Cruz da Cunha LVF, Paiva de Lucena RF, Alves RRN (eds), Methods and Techniques in Ethnobiology and Ethnoecology. Humana Press, New Yrok, Pp.175196.

Williams ET, Lepczyk CA, Morse W, Smith M. 2021. Stakeholder perspective towards the use of toxicants for managing wild pigs. PLoS One. DOI: 10.1371/journal.pone.0246457.

Yi MCK, Mohd-Azlan J. 2020. Wildlife hunting and utilization in Ulu Baleh, Sarawak, Malaysian Borneo. Ethnobiology Letters 11 (1): 7684.

Zainuddin Z. 2019. Sharia and tradition: pig hunting in Minangkabau. International Journal of Scientific and Technology Research 8 (10): 3295-3299. 